\title{
Steroid sulfatase activity in homogenates, microsomes and purified Leydig cells from adult rat testis *
}

\author{
N. Mouhadjer, M. Bedin and G. Pointis
}

U166, groupe de recherches sur l'endocrinologie de la reproduction, INSERM, Maternité Baudelocque, 123, bd de Port-Royal, 75014 Paris, France

(received 12 December 1988, accepted 10 April 1989)

Summary - Steroid sulfatase (STS) activity was studied in the Long-Evans rat testis. The rate of dehydroepiandrosterone sulfate (DHA-S) hydrolysis determined in whole testis homogenates was low compared to that of the corresponding microsomal fractions, which was, in contrast, as high as that expressed in homogenates from purified Leydig cells. Such an increment in STS activity between total homogenate and the corresponding microsomes was not observed for the seminiferous tubules. The STS affinity reported for total testicular microsomes $\left(K_{\mathrm{m}}=3.47 \pm 0.54 \mu \mathrm{M}\right.$; mean $\pm S E M$ ) was of the same magnitude as that previously reported for Leydig cells, but was about 3 times higher than that measured for whole testis homogenate $\left(K_{\mathrm{m}}=10.11 \pm 0.92 \mu \mathrm{M}\right)$. In vivo hCG treatment decreased the STS affinity in total testicular microsomes without affecting this kinetic parameter in whole testis homogenate. These data suggest that the steroid sulfatase expressed in total testicular microsomes (activity and regulation by hCG) could be considered as a good index of Leydig cell STS activity.

steroid sulfatase — rat — testis - Leydig cells - microsomes

Résumé - Activité stéroïde sulfatase dans des préparations purifiées de testicule de rat Long-Evans. L'activité stéroïde sulfatase (STS) a été étudiée dans le testicule de rat Long-Evans. Les homogénats de cellules de Leydig purifiées et la fraction microsomale isolee du testicule entier hydrolysent le sulfate de DHA à des taux équivalents; ces derniers sont nettement supérieurs au taux mesuré dans l'homogénat de testicule entier. L'enrichissement de l'activité STS constaté entre l'homogénat et la fraction microsomale correspondante n'est cependant pas retrouvé au niveau des tubes séminifères. La détermination des valeurs de $\mathrm{K}_{m}$ (moyenne $\pm S E M$ ) montre que laffinité de l'enzyme exprimée dans les microsomes de testicule entier $\left(K_{m}=3,47 \pm 0,54 \mu M\right)$ est du même ordre que celle précédemment rapportée pour les cellules de Leydig; elle est par ailleurs près de 3 fois supérieure à celle de l'enzyme présente dans l'homogénat de testicule entier $\left(K_{m}=10,11 \pm\right.$ $0,92 \mu \mathrm{M})$. Le traitement des rats par hCG diminue l'affinité de l'enzyme dans les microsomes de testicule entier sans affecter ce paramètre dans l'homogénat. Cette étude suggère que l'enzyme mesurée au niveau des microsomes de testicule entier (activité et régulation par hCG) est un bon reflet de l'activité stéroïde sulfatase exprimée par la cellule de Leydig.

activité stéroïde sulfatase - rat - testicule — cellules de Leydig - microsomes

\footnotetext{
* Presented at the 27th meeting of the French Society for Study of Fertility, Paris, 29 September 1 October 1988.
} 


\section{Introduction}

The physiological role of steroid sulfates in the testis is at present incompletely defined. It has been known for a long time that the human testis is able to produce large amounts of steroid sulfates (Laatikainen et al., 1971; Ruokonen et al., 1972). More recent data have shown that these sulfoconjugates can be used as testicular androgen precursors and suggested that steroid sulfatase (STS) may act as a regulatory enzyme for the release of free androgens in humans (Bolton et al., 1985) and boars (Orava et al., 1985). The possible importance of this enzymatic activity in testicular function has been reinforced by the recent description of gonadal abnormalities in patients with STS deficiency (Traupe and Happle, 1983; Lykkesfeldt et al., 1985a). In agreement with previous data (Payne and Jaffe, 1970) suggesting that STS could be a control enzyme in testicular androgen biosynthesis, we have recently shown (Bedin et al., 1988a) that STS activity is also expressed in purified rat Leydig cells. In the present study, we report further investigations on STS expression in this experimental model.

\section{Materials and Methods}

\section{Animals and treatments}

Adult Long-Evans male rats obtained from C.E.R.J. (St.-Berthevin, France) at 3 months of age were housed under standard conditions before sacrifice by decapitation. When the efiect of human chorionic gonadotropin (hCG) was studied, adult male rats were injected intramuscularly (i.m.) with $100 \mathrm{IU}$ of hCG (Organon, France) diluted in saline containing $0.1 \%$ bovine serum albumin (BSA). Control animals were treated with vehicle alone. Both hCG-treated and control rats were killed as described above $2 \mathrm{~h}$ after injection, a lag period resulting in maximal increase in circulating testosterone levels, as previously reported (Haour and Saez, 1977).

\section{Tissue preparations}

Whole testicular interstitial cells from adult Long-Evans rats were prepared by collagenase digestion of decapsulated testes as described previously (Bedin et al., 1988a). The interstitial cells obtained from 5 to 6 rats were further fractionated by centrifugation on continuous Percoll gradients as previously reported (Browning et al., 1981). This cell separation method allowed us to obtain Leydig cells at about $80-85 \%$ purity, as determined by staining for $3 \beta$-hydroxysteroid dehydrogenase. Cell viability $(85 \%)$ was evaluated by trypan blue dye exclusion. Seminiferous tubules were freed of residual interstitial cells by repeated washing with $0.9 \% \mathrm{NaCl}$. Whole testis or seminiferous tubule homogenates from $5-6$ rats were obtained using a Tefion-glass homogenizer in Tris- $\mathrm{HCl}(10 \mathrm{mM})$, sucrose $(0.25 \mathrm{M})$, buffer, $\mathrm{pH} 7.4,(100 \mathrm{mg} / \mathrm{ml})$. When microsomal fractions were required, homogenates were spun at $12000 \times g$ to eliminate cellular debris, nuclei, mitochondria and polyribosomes; the supernatants were subsequently centrifuged at $105000 \times g$ for $1 \mathrm{~h}$ (Purvis et al., 1973) using $10 \mathrm{mM}$ Tris- $\mathrm{HCl}, 0.15 \mathrm{M} \mathrm{KCl}$, $\mathrm{pH} 7.4$, as a buffer. All fractions were kept frozen at $-20^{\circ} \mathrm{C}$ until enzymatic assay.

\section{Enzyme assay}

All cellular or subcellular fractions were homogenized and sonicated before steroid sulfatase activity was determined as reported earlier (Bedin et al., 1988a). Briefly, aliquots of the enzymatic suspension were incubated in duplicate at $37^{\circ} \mathrm{C}$ in $0.1 \mathrm{M}$ Tris- $\mathrm{HCl}, \mathrm{pH} 7.2$, in the presence of labeled dehydroepiandrosterone sulfate $\left(\left[{ }^{3} \mathrm{H}\right]\right.$ DHA-S, sp. act. 24 $\mathrm{Ci} / \mathrm{mmol}$, NEN Chemicals, F.R.G.) at various final concentrations $\left(0.4-40 \times 10^{-6} \mathrm{M}\right)$, in a total reaction volume of $250 \mu \mathrm{l}$. The incubations were stopped after $40 \mathrm{~min}$ by addition of $0.5 \mathrm{ml}$ of $0.1 \mathrm{~N} \mathrm{NaOH}$ and a known amount of $\left[{ }^{14} \mathrm{C}\right]$ DHA was also added as a recovery marker. Blank values were obtained after incubations run simultaneously under the same conditions, except that $\mathrm{NaOH}$ was added before enzymatic suspension. The hydrolysis rate of DHA-S was measured after direct extraction of the liberated unconjugated steroids by the scintillation 
mixture (Toluene-PPO-POPOP) and corrected for methodological losses (80-90\% recovery rate). The reaction rates were linear within the incubation time and the protein range employed. The inter- and intra-assay coefficients of variation were respectively 7 and $5 \%$. Protein concentration was determined by the method of Lowry et al. (1951), using BSA as a standard. When given, the affinity of the enzyme $\left(K_{\mathrm{m}}\right)$ and the maximum velocity of the reaction $\left(V_{\mathrm{m}}\right)$ were calculated from double reciprocal plots according to the LineweaverBurk representation. All experimental data are presented as means \pm SEM of 3 different experiments.

\section{Results}

The rate of DHA-S hydrolysis determined in purified Leydig cells, whole testis and seminiferous tubule homogenates, as well as in microsomal fractions obtained from these last two preparations, is presented in Fig. 1. At the saturating substrate concentration of $2 \times 10^{-5} \mathrm{M}$, the amount of DHA-S cleaved by the whole testis homogenate $(0.60 \pm 0.04 \mathrm{nmol}$ hydrolyzed/mg prot/40 $\mathrm{min}$ ) was low and greatly increased in the corresponding microsomal fraction $(2.08 \pm 0.04 \mathrm{nmol}$ hydrolyzed/mg prot $/ 40 \mathrm{~min}$ ) to a rate similar to the one observed in homogenates of purified Leydig cells $(2.10 \pm 0.29 \mathrm{nmol}$ hydrolyzed $/ \mathrm{mg}$ prot $/ 40$ $\mathrm{min})$. Such an enhancement in the hydrolysis rate was less important between seminiferous tubule homogenates $(0.33 \pm 0.02 \mathrm{nmol}$ hydrolyzed $/ \mathrm{mg}$ prot/40 min) and its corresponding microsomal fraction (0.84 $\pm 0.04 \mathrm{nmol}$ hydrolyzed/mg prot/40 $\mathrm{min})$. The mean \pm SEM apparent $K_{\mathrm{m}}(\mu \mathrm{M})$ and $V_{\mathrm{m}}$ (nmol hydrolyzed/mg prot $40 \mathrm{~min}$ ) values calculated from 3 separate experiments were, respectively, $4.36 \pm 0.38$ and $1.66 \pm$ 0.16 for Leydig cells, $10.11 \pm 0.92$ and $0.77 \pm 0.05$ for whole testis homogenate,

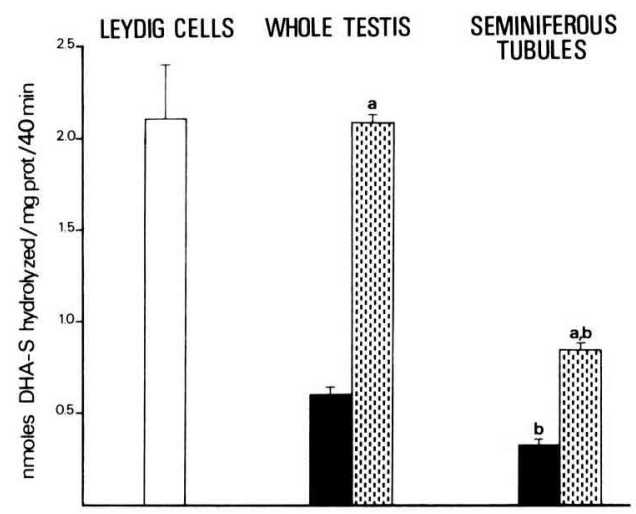

Fig. 1. Specific STS activity measured in Leydig cells and in homogenates (black bars) or microsomes (stippled bars) of the whole testis or seminiferous tubules from Long-Evans rats. Determinations were made at saturating substrate concentration. Results are means \pm SEM of 3 separate experiments. a Significantly different from the corresponding homogenate preparation $(P<0.001)$. b Significantly different from the corresponding whole testis fractions $(P<0.01)$.

$3.47 \pm 0.54$ and $1.32 \pm 0.24$ for whole testis microsomes.

The effect of hCG on the kinetic constants of testicular steroid sulfatase was subsequently studied. Results from 3 separate experiments are presented on Fig. 2. While hCG treatment did not affect either affinity or maximal velocity in the whole testis homogenate, it induced a decrease in affinity in the corresponding microsomal fraction as evidenced by a higher $K_{\mathrm{m}}$ value $\left(K_{\mathrm{m}}=10.18 \pm 1.15 \mu \mathrm{M}\right)$, without modification of velocity.

\section{Discussion}

From studies performed on crude testicular preparations it has been stated that STS activity is present in both the 
HOMOGENATES

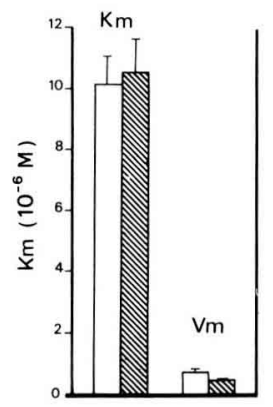

Fig. 2. Effect of an i.m. injection of $100 \mathrm{IU}$ of hCG (hatched bars) on steroid sulfatase kinetic parameters in whole testis homogenates and the corresponding microsomal fractions. Control values (open bars) were determined in similar preparations obtained from salineinjected Long-Evans rats. Results are means \pm SEM of 3 separate experiments. a Significantly different from the respective control $(P<0.01)$.

interstitia and the seminiferous tubules in rats (Payne and Kelch, 1975). However, the relative distribution of this activity between the two compartments and its role in testosterone biosynthesis by Leydig cells are not clearly defined.

The present results confirm and extend our previous data (Bedin et al., 1988a) showing that rat Leydig cells express STS activity. In addition, the hydrolysis rate of DHA-S/mg prot appears to be much higher in this cell type than in seminiferous tubules. These data also indicate that the higher STS activity found by other authors (Van der Vuss et al., 1974; Payne and Kelch, 1975) in interstitial tissue was likely due to Leydig cell STS activity. Considering the fact that Leydig cells are the major site of testosterone production, the present results, together with preliminary results showing that Leydig cells in culture are able to metabolize DHA-S into testosterone (unpublished data), give additional support for considering STS to be involved in testicular testosterone biosynthesis. Although the role of steroid sulfates and STS activity in human testosterone formation has been also hypothesized (Payne et al., 1971), the physiological importance of such a biosynthetic pathway in vivo remains questionable. Indeed, circulating testosterone levels are not or slightly reduced in patients with the ' $X$-linked ichthyosis-STS deficiency' syndrome (Lykkesfeldt et al., 1985b; Ruokonen et al., 1986; Bedin et al., 1988b). Since in some patients elevated $\mathrm{LH}$ levels have been measured, the existence of a compensatory mechanism maintaining normal plasma testosterone levels has been postulated (Lykkesfeldt et al., 1985b).

Our study also shows that DHA-S is hydrolyzed at a similar rate in both Leydig cells and total testicular microsomes, whereas the hydrolysis rate only shows a weak increment in seminiferous tubule microsomes compared to the tubular homogenate; this suggests that tubular microsomes contribute poorly to total microsomal STS activity. From these observations and considering the fact that STS activity is reported to be microsomal in most tissues (Burstein and Dorfman, 1963), it is tempting to speculate that the enzymatic activity present in microsomes prepared from whole testis homogenates reflects the Leydig cell STS. Another, argument in favour of such a similarity between Leydig cells and whole testicular microsomes in terms of STS activity is that hCG treatment modulates the enzyme expression in the latter preparation in a manner similar to that previously reported for Leydig cells (Bedin et al., 1988a). The consistent increase in apparent $K_{\mathrm{m}}$ values noted in whole testis microsomes could be due to competitive inhibition by free steroids (Notation and Ungar, 1969), whose production is 
enhanced after hCG stimulation. This would be likely, since it has been reported that microsomes may concentrate such free steroids (Matsumoto and Samuels, 1969). Such an hypothesis remains to be elucidated.

Since Leydig cells comprise a small percentage of total testicular tissue and LH/hCG specifically regulates this cell type, it is conceivable that no effect of the gonadotrophin could be evidenced when the STS kinetic parameters were determined in the whole testis homogenate. Such an interpretation could explain why hypophysectomy reduces STS activity in the interstitial cells only, without affecting the enzyme activity either in intact tissue or seminiferous tubules (Payne and Kelch, 1975). In contrast to our observation in the rat, human testicular STS activity has been reported to be higher in seminiferous tubules than in intact testicular tissue (Kawano et al., 1973). Nevertheless, these results were obtained using crude homogenates of intact testicular tissue or seminiferous tubules. On the basis of the current study in the rat, using both crude and purified preparations, the evaluation of STS expression in the human testis should be reconsidered.

\section{Acknowledgments}

Authors wish to thank Mrs. Verger for her skillful secretarial assistance.

\section{References}

Bedin M., Fournier T., Mouhadjer N. \& Pointis G. (1988a) Ontogenesis and regulation of steroid sulfatase activity in Leydig cells and seminiferous tubules in the Long-Evans rat. J. Steroid. Biochem. 30, 439-441
Bedin M., Blanchet-Bardon C., Brod J., De Peretti E., Fournier T., Goldstein S., Maziere C., Maziere J.C., Pointis G. \& Vexiau P. (1988b) Steroid sulfatase deficiency, $X$-linked ichthyosis and associated abnormalities (lipoproteins, steroids and gonadal function). $J$. Invest. Dermatol. (in press)

Bolton N.J., Ruokonen A.O. \& Vihko R.K. (1985) Stimulation of the synthesis of steroids and steroid sulfates in human testicular tissue in vitro by hCG and by 8-bromo-cyclic AMP. $J$. Steroid. Biochem. 22, 481-485

Browning J.Y., D'Agata R. \& Grotjan H.E. (1981) Isolation of purifed rat Leydig cells using continuous Percoll gradients. Endocrinology 109, 667-669

Burstein S. \& Dorfman R.J. (1963) Determination of mammalian steroid sulfatase with $7 \alpha-H^{3}-3 B-h y d r o x y$-androst-5-en-17-one sulfate. J. Biol. Chem. 238, 1656-1660

Haour F. \& Saez J.M. (1977) hCG-dependant regulation of gonadotropin receptor sites: negative control in testicular Leydig cells. Mol. Cell. Endocrinol. 7, 17-24

Kawano A., Payne A.H. \& Jaffe R.B. (1973) Gonadal steroid sulfates and sulfatase. VI. Comparative metabolism in isolated seminiferous tubules and minces of human testis. J. Clin. Endocrinol. Metab. 371, 441-447

Laatikainen T., Laitinen E.A. \& Vihko R. (1971) Secretion of free and sulfate-conjugated neutral steroids by human testis. Effect of administration of human chorionic gonadotropin. $J$. Clin. Endocrinol. Metab. 32, 59-64

Lowry O.H., Rosebrough N.J., Farr A.L. \& Randall R.J. (1951) Protein measurement with the Folin phenol reagent. J. Biol. Chem. 193, 265-275

Lykkesfeldt G., Muller J., Shakkebaek N.E., Bruun E. \& Lykkesfeldt A.E. (1985a) Absence of testicular steroid sulfatase activity in a boy with recessive $X$-linked ichthyosis and testicular maldescent. Eur. J. Pediatr. 144, 273-274

Lykkesfeldt G., Bennett P., Lykkesfeldt A.E., Micic S., Maller S. \& Svenstrup B. (1985b) Abnormal androgen and oestrogen metabolism in men with steroid sulfatase deficiency and recessive $X$-linked ichthyosis. Clin. Endocrinol. 23, 385-393

Matsumoto K. \& Samuels L.T. (1969) Influence of steroid distribution between microsomes and soluble fraction on steroid metabolism by microsomal enzymes. Endocrinology 85, 402 409 
Notation A.D. \& Ungar F. (1969) Rat testis steroid sulfatase. 2. Kinetic study. Steroids 14 , 151-159

Orava M., Haour F., Leinonen P., Ruokonen A.O. \& Vihko R.K. (1985) Relationships between unconjugated and sulfated steroids in porcine primary Leydig cell culture. Clin. Endocrinol. 22, 507-512

Payne A.H. \& Jaffe R.B. (1970) Comparative roles of dehydroepiandrosterone sulfate and androstenediol sulfate as precursors of testicular androgens. Endocrinology 87, 316322

Payne A.H., Jaffe R.B. \& Abell M.R. (1971) Gonadal steroid sulfates and sulfatase. III. Correlation of human testicular sulfatase, $3 B$ hydroxysteroid dehydrogenase-isomerase, histologic structure and serum testosterone. $J$. Clin. Endocrinol. Metab. 33, 582-591

Payne A.H. \& Kelch R.P. (1975) Comparison of steroid metabolism in testicular compartments of human and rat testes. In : Hormonal regulation of spermatogenesis. (French F.S., Hansson V., Ritzen E.M. \& Nayfeh S.N., eds.), Plenum Press, New York, pp. 97-108

Purvis J.L., Canick J.A., Latif S.A., Rosenbaum J.H., Hologgitas J. \& Menard R.H. (1973) Lifetime of microsomal cytochrome P-450 and steroidogenic enzymes in rat testis as influenced by human chorionic gonadotrophin. Arch. Biochem. Biophys. 159, 39-49

Rao B., Pointis G. \& Cedard L. (1982) Presence of a chorionic gonadotrophin-like factor in mouse placental cultures during the second half of gestation. J. Reprod. Fert. 66, 341-348

Ruokonen A., Laatikainen T., Laitinen E.A. \& Vihko R. (1972) Free and sulfate-conjugated neutral steroids in human testis tissue. Biochemistry 11, 1411-1416

Ruokonen A., Oikarinen A. \& Vihko R. (1986) Regulation of serum testosterone in men with steroid sulfatase deficiency : response to human chorionic gonadotropin. J. Steroid. Biochem. 25, 113-119

Traupe H. \& Happle R. (1983) Clinical spectrum of steroid sulfatase deficiency : Xlinked recessive ichthyosis, birth complications and cryptorchidism. Eur. J. Pediatr. 140, 19-21

Van Der Vuss G.J., Kalkman M.L. \& Van Der Molen H.J. (1974) 3B-Hydroxysteroid dehydrogenase in rat testis tissue. Inter- and subcellular localization and inhibition by cyanoketone and nagarse. Biochim. Biophys. Acta 348, 404414 